\title{
Effect of intraperitoneally administered IL-1 $\beta$-derived peptides on resistance to viral haemorrhagic septicaemia in rainbow trout Oncorhynchus mykiss
}

\author{
Scott Peddie $^{1,3}$, Pamela E. McLauchlan ${ }^{1,2}$, Anthony E. Ellis ${ }^{2}$, \\ Christopher J. Secombes ${ }^{1, *}$ \\ ${ }^{1}$ School of Biological Sciences, University of Aberdeen, Aberdeen AB24 2TZ, UK \\ ${ }^{2}$ SEERAD Marine Laboratory, PO Box 101, Victoria Road, Aberdeen AB11 9DB, UK \\ ${ }^{3}$ Present address: Animal Health Economics Group, Research \& Development Division, Scottish Agricultural College, \\ Aberdeen AB21 9YA, UK
}

\begin{abstract}
The present work provides the first information concerning the immunostimulatory activity of trout interleukin (IL)-1 $\beta$-derived peptides in vivo. Previous studies have demonstrated the ability of 2 such peptides, referred to as P1 and P3, to up-regulate a range of important immune parameters in vitro. P1 corresponds to fragment 146-157 (YVTPVPIETEAR) of the trout sequence and is analogous to a biologically active mammalian IL-1 $\beta$-derived peptide, whilst P3 was synthesised to complex with the IL-1 receptor and corresponds to fragment 197-206 (YRRNTGVDIS) of the trout sequence. Optimal migration of peritoneal leucocytes, peptide induced phagocytosis and intracellular respiratory burst activity occurred following intraperitoneal injection of $3.0 \mu \mathrm{mol}$ of P3. Furthermore, resistance to viral haemorrhagic septicaemia virus (VHSV) was soon augmented (2 d) post-injection of P3.
\end{abstract}

KEY WORDS: Interleukin-1 $\beta$ - Phagocytosis - Respiratory burst - Disease resistance $\cdot$ Immunomodulation $\cdot$ VHS

Resale or republication not permitted without written consent of the publisher

\section{INTRODUCTION}

Recent studies have demonstrated that rainbow trout Oncorhynchus mykiss recombinant interleukin-1 $\beta$ (rIL-1 $\beta$ ) enhances the expression of several immune genes (IL-1 $\beta$ itself, COX-2 and MHC class II $\beta$ ), in addition to augmenting head kidney phagocytic activity and leucocyte migration in vitro (Hong et al. 2001, Peddie et al. 2001). In vivo studies have confirmed that intraperitoneally administered rIL- $1 \beta$ enhances phagocytosis and leucocyte migration in the peritoneal cavity, in addition to increasing IL-1 $\beta$, COX-2 and lysozyme II gene expression in head kidney and gill tissue (Hong et al. in press). Moreoever, rIL-1 $\beta$ has also been shown to enhance resistance to the bacterial pathogen Aeromonas salmonicida, both in vitro (Peddie 2002) and in vivo (Hong et al. 2003).

Peptides derived from the trout IL- $1 \beta$ molecule have recently been synthesised and tested for their bioactivity in vitro (Peddie et al. 2001, 2002a). The most bioactive peptide, known as P3, was synthesised to complex with the IL-1 receptor and corresponds to fragment 197-206 (YRRNTGVDIS) of the trout sequence. A second peptide, referred to as P1, corresponds to fragment 146-157 (YVTPVPIETEAR) of the trout sequence and is analogous to a biologically active mammalian IL-1 $\beta$-derived peptide (Peddie et al. 2001). P3 enhances leucocyte migration (Peddie et al. 2001), phagocytosis (Secombes et al. 2001, Peddie et al. 2002a) and bactericidal activity of head kidney leuco- 
cytes (Peddie et al. 2002a). Although bioactive in its own right, the ability of $\mathrm{P} 1$ to enhance leucocyte migration and phagocytosis is enhanced when it is combined with P3 (Peddie et al. 2001, 2002a).

The aim of this paper is to investigate the ability of IL-1 $\beta$-derived peptides, particularly P3, to enhance leucocyte migration, phagocytic activity and superoxide anion production in the peritoneal cavity of rainbow trout. Furthermore, the ability of these peptides to enhance resistance to viral haemorrhagic septicaemia virus (VHSV) is ascertained.

\section{MATERIALS AND METHODS}

Production of peptides. Three peptides, referred to as P1, P2 and P3, were synthesised at the Proteome Facility, University of Aberdeen, Scotland, UK. P1 corresponded to fragment 146-157 (YVTPVPIETEAR) of the trout IL-1 $\beta$ sequence (Zou et al. 1999), and had a molecular weight (MW) of $1.37 \mathrm{kDa}$. P2 was used as an immunologically irrelevant peptide and consisted of the same 12 amino acids as $\mathrm{P} 1$, but arranged in a random sequence (VVEEYIRAPPTT). P3 corresponded to fragment 197-206 (YRRNTGVDIS) of the trout sequence and had a MW of $1.18 \mathrm{kDa}$. Additional details of each peptide are presented in Peddie et al. (2001).

Peptides were dissolved in $10 \mathrm{ml}$ sterile $0.15 \mathrm{M}$ phosphate buffered saline (PBS, Gibco), pH 7.2, and sonicated on ice. Stock solutions $(10 \mathrm{mM})$ were stored in $0.5 \mathrm{ml}$ aliquots at $-80^{\circ} \mathrm{C}$ until required. Final concentrations were obtained by diluting the necessary volume of stock solution in sterile PBS.

Fish maintenance. Rainbow trout weighing 100 to $500 \mathrm{~g}$ were obtained from Almondbank trout farm (Perthshire, UK), stocked in 2501 tanks at the Zoology Department, University of Aberdeen, maintained at $12 \pm 1^{\circ} \mathrm{C}$, with a constant flow of aerated and dechlorinated mains water. For the VHSV challenge experiment, trout (average weight $10 \mathrm{~g}$ ) were maintained at the SEERAD Marine Laboratory, Aberdeen. Fish were fed ad libitum daily with commercial pellets (Ewos). An acclimation period of $2 \mathrm{wk}$ was observed prior to the start of each experiment.

Peritoneal cell migration. Five groups of 6 fish (average weight $100 \mathrm{~g}$ ) were anaesthetised with benzocaine (ethyl-4-aminobenzoate, BDH) solution (4 mg $\mathrm{ml}^{-1}$ of ethanol) diluted in water. Each fish was injected intraperitoneally with $500 \mu \mathrm{l}$ of either PBS (negative control), lipopolysacharide (LPS) (100 $\mu \mathrm{g}$ Escherichia coli 0127:B8, Sigma; positive control), or $1.5 \mu \mathrm{mol}$ of P1, P2 or P3. At 1 and 3 d post-injection, peritoneal cells were harvested using the methodology as described in Peddie et al. (2002b) and Hong et al. (2003). Briefly, killed fish were injected intraperitoneally with $5 \mathrm{ml}$
$\mathrm{Ca}^{2+}$ and $\mathrm{Mg}^{2+}$ free Hanks balanced salt solution (HBSS-CMF, Gibco) supplemented with $10 \mathrm{U} \mathrm{ml}^{-1}$ heparin (Sigma). After making a small incision in the peritoneal wall, peritoneal exudates were harvested and subsequently centrifuged at $400 \times g$ for $15 \mathrm{~min}$ at $4{ }^{\circ} \mathrm{C}$. Total numbers of peritoneal cells per fish were calculated by resuspending the cells in $1 \mathrm{ml}$ of HBSS$\mathrm{CMF}$ medium and performing direct counts in a haemocytometer viewed at $400 \times$ magnification.

Approximately $100 \mu \mathrm{l}$ of the cell suspensions from fish treated with LPS and $1.5 \mu \mathrm{mol}$ P3 for $1 \mathrm{~d}$ in vivo was used to assess the relative numbers of leucocyte subpopulations (macrophages, neutrophils and lymphocytes) by light microscopy, as outlined in Hong et al. (2003). Isolated cells were centrifuged at $400 \times g$ for 15 min, re-suspended in PBS at 1:5 v/v, and $100 \mu \mathrm{l}$ of the resultant suspension smeared onto a microscope slide. After air drying, slides were fixed in methanol and stained in Giemsa diluted 1:10 in PBS for $50 \mathrm{~min}$. Differential cell counts were carried out at $400 \times$ by counting between 50 and 200 cells per slide. Cells were identified on the basis of morphology and cell ultrastructure as documented in previous fish leucocyte studies (Ellis 1977, Rowley 1990, Afonso et al. 1997).

A further experiment was performed using an increased number of concentrations of P3 $(0.15,1.5$ and $3 \mu \mathrm{mol} \mathrm{fish}{ }^{-1}$ ) to elucidate more precisely the nature of the dose-response relationship. In this experiment, 5 fish per group (average weight $100 \mathrm{~g}$ ) were injected intraperitoneally with $500 \mu \mathrm{l}$ of the test substance. PBS was used as a negative control. Peritoneal leucocytes were harvested at $1 \mathrm{~d}$ post-injection and overall counts performed.

Phagocytic activity of elicited peritoneal leucocytes. Four groups of 5 fish (average weight $100 \mathrm{~g}$ ) were injected with $500 \mu \mathrm{l}$ of either PBS (negative control), $0.15,1.5$ or $3 \mu \mathrm{mol}$ P3. Phagocytic activity in peritoneal leucocytes at $1 \mathrm{~d}$ post-injection was quantified using light microscopy as documented in Peddie et al. (2002b). Briefly, peritoneal cells from each fish were harvested at $1 \mathrm{~d}$ post-injection and re-suspended in 1 to $2 \mathrm{ml}$ of Leibovitz medium (L-15, Gibco) containing $2 \%$ foetal calf serum (FCS, Gibco), heparin (10 $\left.\mathrm{U} \mathrm{ml}^{-1}\right)$ and penicillin $\left(100 \mu \mathrm{g} \mathrm{ml}^{-1}\right) /$ streptomycin $\left(100 \mathrm{U} \mathrm{ml}^{-1}\right)$ (P/S, Gibco). Viable cell counts were carried out using the trypan blue (Sigma) exclusion test, with final numbers adjusted to $1 \times 10^{5}$ cells ml $\mathrm{m}^{-1} \mathrm{~L}-15$ medium. One $\mathrm{ml}$ of the cell suspension was placed on a methanol cleaned glass slide. Macrophages/neutrophils were allowed to adhere for $1 \mathrm{~h}$ in a humidity chamber, in the dark, at $18^{\circ} \mathrm{C}$. After washing off non-adherent cells with HBSS, the slides were flooded with $1 \mathrm{ml}$ of denatured yeast suspension $\left(1.2 \times 10^{8}\right.$ cells ml ${ }^{-1}$ culture medium/phosphate buffer at a ratio of 1:1). Phagocyto- 
sis was allowed to proceed for $1 \mathrm{~h}$ in the humidity chamber before excess yeast was washed off with HBSS and the slides air dried. After methanol fixation, the slide preparations were stained sequentially with May-Grunwald (BDH) and Giemsa. Slides were viewed under oil immersion at 1000x. Approximately 100 cells were counted in random fields of view, and the number of leucocytes that had phagocytosed yeast cells (\% phagocytosis) and the number of yeast particles phagocytosed per cell (phagocytic index) were recorded.

Effects on disease resistance. Viral challenge experiments were carried out at the SEERAD Marine Laboratory, Aberdeen. In the first experiment, 3 groups of 25 rainbow trout, mean weight $10 \mathrm{~g}$, were anaesthetised using benzocaine $\left(4 \mathrm{mg} \mathrm{ml}^{-1}\right.$ of ethanol, diluted in water) and injected intraperitoneally with $30 \mu \mathrm{l}$ of a range of doses of P3 $(0.015,0.15$ and $0.3 \mu \mathrm{mol}$ $\mathrm{fish}^{-1}$ ). The dose range was chosen to mirror that used in previous experiments, although it was reduced 10fold to take into account the corresponding reduction in fish weight. The control group, which consisted of a further 25 fish, was injected with PBS alone. The different groups were distinguished by means of groupspecific alcian blue pan-jet markings applied to the ventral surface. Two and $7 \mathrm{~d}$ after P3/PBS administration, the fish were bath challenged with VHSV. This procedure consisted of immersing the fish for $2 \mathrm{~h}$ in constantly aerated water containing $1 \times 10^{5} 50 \%$ tissue infective dose $\left(\mathrm{TCID}_{50}\right) \mathrm{VHSV} \mathrm{ml}{ }^{-1}$. Fish were then transferred to a $600 \mathrm{l}$ tank supplied with aerated and dechlorinated tap water $\left(12 \pm 1^{\circ} \mathrm{C}\right)$. Dead fish were collected daily and cumulative mortality was calculated over the $28 \mathrm{~d}$ duration of the experiment.

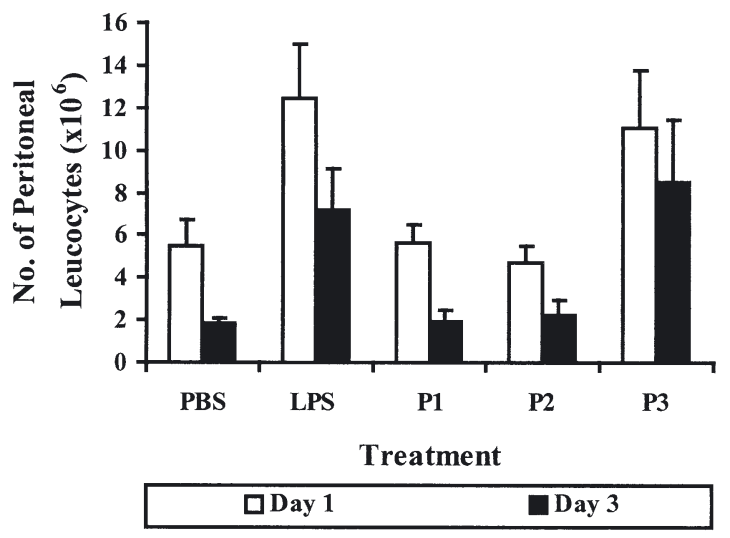

Fig. 1. Oncorhynchus mykiss. Effect of intraperitoneally administered P1, P2 and P3 (all at $1.5 \mu \mathrm{mol} \mathrm{fish}{ }^{-1}$ ) on the number of leucocytes in trout peritoneal exudates at 1 and $3 \mathrm{~d}$ post-injection. Cells were viewed under a light microscope at 400x magnification. Phosphate buffered saline (PBS) was used as a negative control, whilst lipopolysacharide was used as a positive control. Data are expressed as means + SE of 6 fish
Data analysis. Assessment of whether parametric or non-parametric statistical tests were appropriate for each data set was made following the application of the Anderson-Darling Normality Test. Consequently, peritoneal leucocyte counts, phagocytosis and NBT reduction were analysed using either 2-way or 1-way ANOVA, followed by 2 sample $t$-tests or Tukey's pairwise comparisons tests, as appropriate. Mann-Whitney $U$-tests were employed to elucidate the statistical significance of any inter-group differences in specific leucocyte sub-populations. Finally, the group mortality curves obtained in the disease challenge experiments were analysed by the log-rank test as described by Peto et al. (1977).

\section{RESULTS}

\section{Peritoneal cell migration}

Overall, there was a significant effect of both group $(p<0.001)$ and day $(p<0.05)$ on peritoneal leucocyte numbers, as determined by 2-way ANOVA (Fig. 1). There was no significant interaction between these 2 parameters. Analysis of Day 1 and 3 data revealed significant differences in peritoneal leucocyte numbers as a function of treatment $(\mathrm{p}<0.05)$, with P3-treated fish exhibiting the greatest effect. Two sample $t$-tests showed that there was a significant decrease in leucocyte numbers between Days 1 and 3 in the PBS, P1 and P2 treated groups $(\mathrm{p}<0.05)$. However, there were no significant decreases in the LPS and P3 injected fish. The group injected with $1.5 \mu \mathrm{mol} \mathrm{P} 3 \mathrm{fish}^{-1}$ exhibited a significantly lower proportion of macrophages in the peritoneal exudates than the LPS injected group at $1 \mathrm{~d}$ post-injection ( $p<0.05$, by Mann-Whitney $U$-test). The proportion of neutrophils was significantly higher in the P3 treated group, whilst the relative number of lymphocytes was significantly lower $(\mathrm{p}<0.05)$ (Fig. 2). Relative to the control peritoneal leucocyte counts (see Fig. 2 legend), P3 injected fish exhibited significantly different proportions of neutrophil and macrophages ( $p<0.05$, by Mann-Whitney $U$-test).

P3 had a clear, dose-dependent effect on the total number of leucocytes migrating into the peritoneal cavity at $1 \mathrm{~d}$ post-injection $(\mathrm{p}<0.001$, by 1 -way ANOVA) (Fig. 3). Tukey's pairwise comparisons test showed that 0.15 and $1.5 \mu \mathrm{mol} \mathrm{fish}^{-1}$ were insufficient to significantly enhance migration relative to the control. However, $1.5 \mu \mathrm{mol}$ P3 elicited a significantly greater influx of leucocytes into the peritoneal cavity than $0.15 \mu$ mol P3 $(p<0.05)$. Moreover, a dose of $3.0 \mu \mathrm{mol}$ P3 enhanced migration further $(p<0.05)$, resulting in a leucocyte count almost twice that of the PBS injected controls. 


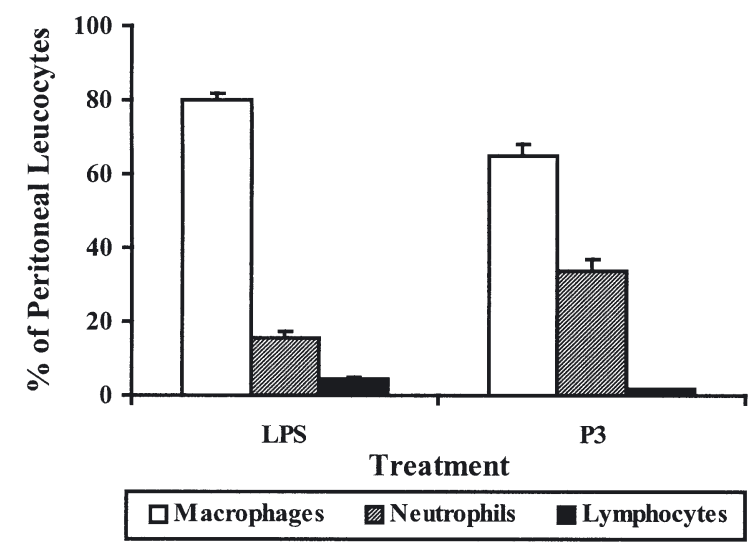

Fig. 2. Oncorhynchus mykiss. Effect of intraperitoneally administered P3 $\left(1.5 \mu \mathrm{mol}\right.$ fish $\left.^{-1}\right)$ on leucocyte composition in trout peritoneal exudates at $1 \mathrm{~d}$ post-injection. Cells were stained with Giemsa, viewed under a light microscope at $400 \times$ magnification and identified based on a range of morphological characteristics. Lipopolysacharide was used as a positive control. Data are expressed as means + SE of 6 fish. Control peritoneal leucocytes were as follows: $73.0 \pm 1.2 \%$ macrophages, $21.2 \pm 2.0 \%$ neutrophils and $5.8 \pm 1.3 \%$ lymphocytes

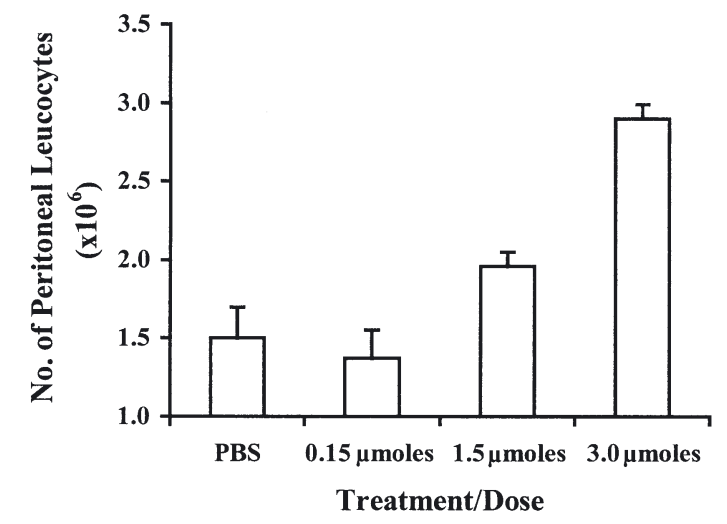

Fig. 3. Oncorhynchus mykiss. Effect of a range of doses of intraperitoneally administered P3 $\left(0.15,1.5\right.$ and $\left.3 \mu \mathrm{mol} \mathrm{fish}^{-1}\right)$ on the number of leucocytes in trout peritoneal exudates at $1 \mathrm{~d}$ post-injection. Phosphate buffered saline (PBS) was used as a negative control. Cells were viewed under a light microscope at $400 \times$ magnification. Data are expressed as means + SE of 6 fish

\section{Phagocytic activity of elicited peritoneal leucocytes}

Although there was no significant effect on \% phagocytosis in P3 elicited peritoneal leucocytes (data not shown), there was a significant dose-dependent effect of P3 on phagocytic index ( $p<0.001$, by 1 -way ANOVA) (Fig. 4). Thus, although the overall proportion of cells actively phagocytosing yeast particles was unaffected by P3 treatment, the average number of yeast cells ingested per phagocyte increased. A dose of $\geq 1.5 \mu \mathrm{mol}$ resulted in a significant increase in the phagocytic index of peritoneal leucocytes $(p<0.05$, by

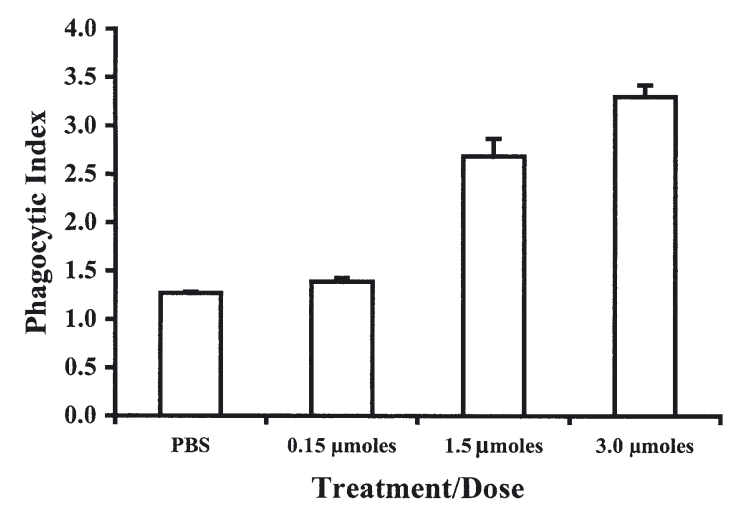

Fig. 4. Oncorhynchus mykiss. Effect of a range of doses of P3 $\left(0.15,1.5\right.$ and $\left.3 \mu \mathrm{mol} \mathrm{fish}^{-1}\right)$ on the phagocytic index in peritoneal leucocytes harvested at $1 \mathrm{~d}$ post-injection. Phosphate buffered saline (PBS) was used as a negative control. Leucocytes were allowed to adhere to microscope slides for $1 \mathrm{~h}$ and subsequently incubated with yeast cells $\left(1.2 \times 10^{8}\right.$ cells ml $^{-1}$ $\mathrm{L}-15$ :PBS at a ratio of $1: 1$ ) for $1 \mathrm{~h}$ at $18^{\circ} \mathrm{C}$. Preparations were stained sequentially with May-Grunwalds and Giemsa and viewed at 1000x under oil immersion. Data are expressed as means + SE of 6 fish

Tukey's pairwise comparison test), with a peak response occurring at the highest dose tested $(3.0 \mu \mathrm{mol}$ fish $^{-1}$ ).

\section{Effects on disease resistance}

Administration of P3 $2 \mathrm{~d}$ prior to challenge, at all 3 doses tested $\left(0.015,0.15\right.$ and $0.3 \mu \mathrm{mol}$ fish $\left.^{-1}\right)$, significantly reduced mortality rates in trout exposed to VHSV ( $p<0.001$, by log-rank test) (Fig. 5A). Although there were no significant differences between the P3 treated groups, overall mortality rates were reduced by $28 \%$ in the 0.015 and $0.3 \mu \mathrm{mol}$ injected fish, and $20 \%$ in the $0.15 \mu \mathrm{mol}$ injected fish. However, there was no significant reduction in mortality as a consequence of P3 administration $7 \mathrm{~d}$ prior to VHSV disease challenge (Fig. 5B), when mortality was 64 and $60 \%$ in the PBS and P3 injected fish, respectively. Whilst control peptide P2 was not used in these studies, previous work which looked at the induction of several immune genes post-injection of IL-1 derived peptides has shown that, in contrast to P3, P2 has no significant effects on any gene examined (Hong 2002). Therefore, P2 would not be expected to give results different to the PBS group.

\section{DISCUSSION}

In the current study, the IL-1 $\beta$-derived peptide P3 induced leucocyte migration into the peritoneal cavity of trout at 1 and $3 \mathrm{~d}$ post-injection. In contrast to previ- 

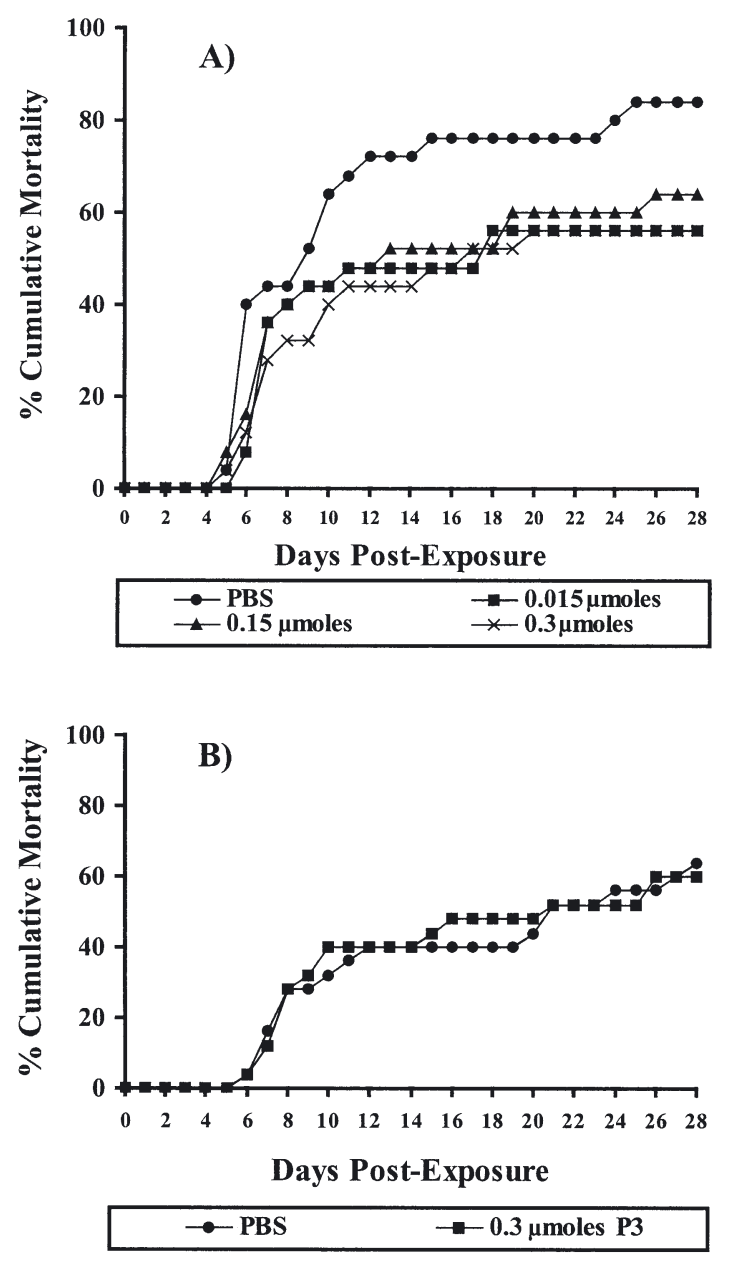

Fig. 5. Oncorhynchus mykiss. Mortality in trout injected with (A) either phosphate buffered saline (PBS; control) or a range of concentrations of P3 $\left(0.015,0.15\right.$ and $\left.0.3 \mu \mathrm{mol} \mathrm{fish}{ }^{-1}\right)$ and bath challenged with $1 \times 10^{5} 50 \%$ tissue infective dose $\left(\mathrm{TCID}_{50}\right)$ viral heamorrhagic septicaemia virus (VHSV) $\mathrm{ml}^{-1}$ 2 d later, or (B) either PBS (control) or $0.3 \mu \mathrm{mol} \mathrm{P} 3 \mathrm{fish}^{-1}$ and bath challenged $7 \mathrm{~d}$ later. Cumulative mortality for each treatment was calculated over the $28 \mathrm{~d}$ duration of the trial

ous in vitro studies (Peddie et al. 2001), P1 and P2 were unable to elicit migration to any significant degree. This may be because P3 is capable of eliciting production of secondary factors in vivo (Peddie 2002), thus further augmenting migration. Analysis of leucocyte sub-populations revealed a similar pattern to rIL-1 $\beta$ injected fish (Hong et al. 2003), for which neutrophils were the most abundant sub-type. However, this effect was not significant in the fish treated with the full IL-1 $\beta$ sequence until $3 \mathrm{~d}$ post-injection. The dose-dependent nature of P3 induced migration was also elucidated, and the maximal response obtained was for $100 \mathrm{~g}$ fish injected with $3.0 \mu \mathrm{mol}$ of peptide (the highest concentration tested). The fact that a decrease in migration was not seen at the highest concentrations investi- gated suggests that receptor saturation/desensitisation had not occurred over the concentration range used. The extent to which peritoneal leucocytes phagocytosed yeast particles, as measured by the phagocytic index, was also modulated by P3 in a dose-dependent manner, and the peak response again occurred at the highest dose tested $(3.0 \mu \mathrm{mol})$. Therefore, P3 can be added to the extensive list of immunostimulants that enhance phagocyte activity in fish; this includes: yeast$\beta$ glucan (Anderson 1992, Jeney \& Anderson 1993), scleroglucan and zymosan (Wang \& Wang 1997), and Ergosan (Peddie et al. 2002b).

An important finding of the current study was that a range of doses of P3 $(0.015,0.15$ and $0.3 \mu \mathrm{mol})$ administered to $10 \mathrm{~g}$ fish resulted in reduced mortality rates following exposure to VHSV 2 d later. Although immunity to viruses in fish is poorly understood, the full mammalian IL-1 $\beta$ molecule is known to inhibit viral reproduction via direct and indirect mechanisms in mammalian models (Iwata et al. 1999, Togashi et al. 2000). IL-1 up-regulates TNF- $\alpha$ and iNOS expression in such systems, both of which have potent anti-viral properties (Togashi et al. 2000, Lokensgard et al. 2001). Recently, iNOS and TNF- $\alpha$ have been fully sequenced in fish (Saeij et al. 2000, Wang et al. 2001, Laing et al. 2001), thus providing a possible pathway for peptide-induced anti-viral activity. Indeed, Tafalla et al. (1999) demonstrated that nitric oxide decreases VHSV replication in turbot macrophages in vitro.

In contrast, when fish were exposed to the infectious agent $7 \mathrm{~d}$ after P3 administration, no reduction in mortality occurred. Although the level of mortality in the control group varied between experiments $(60 \%$ after $10 \mathrm{~d}$ in the first experiment, as opposed to $40 \%$ in the second), this was most likely due to a different batch of virus used for challenge, or that handling stress influenced mortality in the short-term. Although the precise reason for the variation in mortality level is unknown, it seems clear that in the absence of further stimulation, the effect of P3 on the immune system is short-lived, at least with respect to overall disease resistance. Research aimed at prolonging peptide induced immunostimulation in the piscine model is therefore required. Mammalian studies have shown that a wide range of lipsomes and microspheres can be used to improve immunostimulant/vaccine absorption efficiency and duration of effect (Ahsan et al. 2002). Novel delivery vehicles such as physicochemically modified ovalbumin microsphere matrices (Puri \& Sinko 2000), poly (ethylene glycol)-coated poly (lactic acid) nanoparticles (Vila et al. 2002) and poly (DLlactide-co-glycolide) microspheres (Garcia et al. 1999) have shown promising results.

In conclusion, the immunostimulatory property of an intraperitoneally administered IL-1 $\beta$-derived pepide 
has been demonstrated in rainbow trout. Optimal migration of peritoneal leucocytes and peptide induced phagocytosis occurred following injection of $3.0 \mu \mathrm{mol}$ of the peptide. Resistance to VHSV was also augmented following injection of P3, albeit a shortterm effect. Further studies of the mechanisms by which IL-1 $\beta$-derived peptides induce these effects in vivo are needed.

Acknowledgements. This work was supported by a BBSRC Industrial CASE studentship to S.P., with Aquaculture Vaccines. Thanks go to Dr. Suhee Hong for practical help with fish sampling.

\section{LITERATURE CITED}

Afonso A, Ellis AE, Silva MT (1997) The leucocyte population of the unstimulated peritoneal cavity of rainbow trout (Oncorhynchus mykiss). Fish Shellfish Immunol 7:335-348

Ahsan F, Rivas IP, Khan MA, Torres Suarez AI (2002) Targeting to macrophages: role of physiochemical properties of particulate carriers-liposomes and microspheres-on the phagocytosis by macrophages. J Cont Rel 79:29-40

Anderson DP (1992) Immunostimulants, adjuvants and vaccine carriers in fish: applications to aquaculture. Annu Rev Fish Dis 2:281-307

Ellis AE (1977) The leucocytes of fish: a review. J Fish Biol 11: 453-491

Garcia JT, Farina JB, Munguia O, Llabres M (1999) Comparative degradation study of biodegradable microspheres of poly (DL-lactide-co-glycolide) with poly (ethyleneglycol) derivatives. J Microencapsulation 16:83-94

Hong S (2002) Bioactivity of recombinant IL-1 $\beta$ and derived peptides, and analysis of IL- $1 \beta$ processing in rainbow trout, Oncorhynchus mykiss. PhD thesis, University of Aberdeen

Hong S, Zou J, Crampe M, Peddie S, Scapigliatti G, Secombes CJ (2001) Production and bioactivity testing of rainbow trout (Oncorhynchus mykiss) recombinant IL-1 $\beta$. Vet Immunol Immunopathol 81:1-14

Hong S, Peddie S, Campos-Pérez JJ, Zou J, Secombes CJ (2003) The effect of intraperitoneally administered recombinant IL-1 $\beta$ on immune parameters and resistance to Aeromonas salmonicida in the rainbow trout (Oncorhynchus mykiss). Dev Comp Immunol 27:801-812

Iwata M, Vieira J, Byrne M, Horton H, Torok-Storb B (1999) Interleukin-1 (IL-1) inhibits growth of cytomegalovirus in human marrow stromal cells: inhibition is reversed upon removal of IL-1. Blood 94:572-578

Jeney G, Anderson DP (1993) Glucan injection or bath exposure given alone or in combination with a bacterin enhance the non-specific defence mechanisms in rainbow trout (Oncorhynchus mykiss). Aquaculture 116:315-329

Laing KJ, Wang T, Zou J, Holland J and 5 others (2001) Cloning and expression analysis of rainbow trout Oncorhynchus mykiss tumour necrosis factor- $\alpha$. Eur J Biochem 268:1315-1322

Lokensgard JR, Hu SX, Shen W, van Oijen M, Cox D, Cheeran MCJ, Peterson PK (2001) Robust expression of TNF-alpha, IL-1 beta, RANTES, and IP-10 by human

Editorial responsibility: Donald Evans,

Athens, Georgia, USA microglial cells during non-productive infection with herpes simplex virus. J Neurovirology 7: 208-219

Peddie S (2002) The effects of novel immunostimulants on immunity and disease resistance in the rainbow trout (Oncorhynchus mykiss). PhD thesis, University of Aberdeen

Peddie S, Zou J, Secombes CJ (2001) Rainbow trout (Oncorhynchus mykiss) recombinant IL-1 beta and derived peptides induce migration of head kidney leucocytes in vitro. Fish Shellfish Immunol 11:697-709

Peddie S, Zou J, Secombes CJ (2002a) A biologically active IL-1 $\beta$ derived peptide stimulates phagocytosis and bactericidal activity in rainbow trout, Oncorhynchus mykiss (Walbaum) head kidney leucocytes in vitro. J Fish Dis 25: 351-360

Peddie S, Zou J, Secombes CJ (2002b) Immunostimulation in the rainbow trout (Oncorhynchus mykiss) following intraperitoneal administration of Ergosan. Vet Immunol Immunopathol 86:101-113

Peto R, Pike MC, Armitage P, Breslow NE and 6 others (1977) Design and analysis of randomised clinical trials requiring prolonged observation of each patient. Br J Cancer 35: $1-39$

Puri N, Sinko PJ (2000) Adjuvancy enhancement of muramyl dipeptide by modulating its release from a physicochemically modified matrix of ovalbumin microspheres II. In vitro investigation. J Cont Rel 69:69-80

Rowley AF (1990) Collection, separation and identification of fish leukocytes. In: Stolen JS, Fletcher TC, Anderson DP, Robertsen BS, van Muiswinkel WB (eds) Techniques in Fish Immunology-I. SOS Publications, Fair Haven, NJ, p 113-136

Saeij JPJ, Stet RJM, Groeneveld A, Verburg-van Kemenade BML, van Muiswinkel WB, Wiegertjes GF (2000) Molecular and functional characterization of a fish inducible-type nitric oxide synthase. Immunogenetics 51:339-346

Secombes CJ, Wang T, Hong S, Peddie S, Crampe M, Laing KJ, Cunningham C, Zou J (2001) Cytokines and innate immunity of fish. Dev Comp Immunol 25:713-723

Tafalla C, Medina I, Figueras A, Novoa B (1999) Production of leukotriene B-4 and prostaglandin E-2 by turbot (Scophthalmus maximus) leukocytes. Comp Biochem Physiol B Biochem Mol Biol 123:351-356

Togashi H, Ohno S, Matsuo T, Watanabe H, Saito T, Shinzawa $H$, Takahashi $T$ (2000) Interferon-gamma, tumor necrosis factor-alpha, and interleukin 1-beta suppress the replication of hepatitis B virus through oxidative stress. Res Comm Mol Pathol Pharmacol 107:407-417

Vila A, Sanchez A, Tobio M, Calvo P, Alonso MJ (2002) Design of biodegradable particles for protein delivery. J Cont Rel 78:15-24

Wang TH, Ward M, Grabowski, P, Secombes CJ (2001) Molecular cloning, gene organization and expression of rainbow trout (Oncorhynchus mykiss) inducible nitric oxide synthase (iNOS) gene. Biochem J 358:747-755

Wang WS, Wang DH (1997) Enhancement of the resistance of tilapia and grass carp to experimental Aeromonas hydrophila and Edwardsiella tarda infections by several polysaccharides. Comp Immunol Microbiol Infect Dis 20: 261-271

Zou J, Cunningham C, Secombes CJ (1999) The rainbow trout Oncorhynchus mykiss interleukin- $1 \beta$ gene has a different organisation to mammals and undergoes incomplete splicing. Eur J Biochem 259:901-908

Submitted: September 19, 2002; Accepted: May 28, 2003

Proofs received from author(s): August 27, 2003 